\title{
Modern trends in the formation of the quality system of higher education
}

\author{
Gulsharat Minazheva* \\ Al-Farabi Kazakh National University, 050040, 71, al-Farabi Ave, Almaty, Kazakhstan
}

\begin{abstract}
The trends in the formation, development of the quality assurance system of education, reveals the prerequisites for the creation and theoretic-pedagogical basis of the formation of the quality assurance system of education, and the history of the development of mechanisms to ensure the quality of higher education are considered in the article. The world integration processes, the international practice of forming a national system for ensuring the quality of higher education are considered. The chronology of reforms and transformations taking place in the field of education is also given. Based on a comparative-historical analysis of the formation of the quality assurance system of higher education in European countries, two periods are identified and characterized: the period before the Bologna processes; period - after the Bologna processes. Based on the analysis of world experience, the division of the existing systems of assessment of higher education into different types is shown.
\end{abstract}

\section{Introduction}

The transition of Kazakhstan to a market economy has reduced to the necessity for an adequate reaction and quickly adaptation of education to changes in society, and was the main cause for the development of basically new methods to management and improving the quality of education.

In the Message to the people of Kazakhstan "Competitive Kazakhstan, a competitive economy, a competitive nation!" The first President of the country, Elbasy N. Nazarbayev noted that "full integration into the global educational space requires raising the education system to the international level. ... Kazakhstan should as soon as possible adopt almost half a century of experience of Western countries in managing product quality, in addition, at an accelerated pace, move to international ISO standards" [1].

In light of the decisions set by the head of state, the central tendencies in ensuring the quality of education are orientation toward students' requests and the finding of optimal conditions for their education and development. Moreover, the quality of education is considered as a comprehensive indicator synthesizing all stages of the formation of personality, conditions and results of the educational process, as well as a criterion for the effectiveness of the educational institution, the compliance of real results with regulatory requirements, social and personal expectations. At the same time, for higher education, focusing on the needs of the employer is becoming increasingly important. Assessing the quality of education in this case is not of independent interest, but is considered as the key to

\footnotetext{
* Corresponding author: Gulsharat.Mynazheva@kaznu.kz
} 
solving urgent practical problems in the country's economy, where education is the main component.

Recently, views on higher education and its quality have been changing rapidly. Among the many problems faced by universities in the 21 st century, the crucial and simultaneously complex is the problem of quality. If in the last century, the activities of the higher education system and individual universities in various countries were estimated mainly by quantitative indicators (number of students per 10 thousand inhabitants; the share of GDP allocated for higher education; teacher / student ratio; the amount of funding for universities, etc.), then in conditions of market relations, ensuring the quality of education and evaluating the effectiveness of universities, meeting modern requirements and international indicators in this area are of paramount importance.

In order to understand the nature and driving mechanisms in improving of the quality management system of higher education, we consider some general conditions and patterns that directly affect the quality of education and the education sector as a whole.

In recent years, higher education from the elite becomes widespread. The quantity of university students in the world enhanced to 84.26 million people in 2000 year. As forecasts confirm by the international investment firm Meryl Lang, Peer, Fenner and Smith [2], the necessity for higher education on the planet may reach 160 million training places in 2025 year.

Today, the majority of high school graduates enter universities.

In Kazakhstan, access to higher education has expanded significantly in recent years. The number of state educational grants is increasing [3]. This trend is characteristic not only of Kazakhstan and the CIS countries. In some developed countries, The percentage of the people receiving higher education has grown in the last quarter of a century from 25 to $80 \%$ [4].

The percentage of students who have received higher education in Russia in the beginning of the millennium was $35 \%$ against $18 \%$ in 1995 [5].

In a number of countries of the world [6] the market orientation of education is increasing, the role of such utilitarian parameters as cost, duration, quality, and readiness of graduates for social and professional activity is increasing.

The processes of globalization, Europeanization and internationalization of higher education are increasing. And here, the higher education system is faced with the fundamental question of the relationship between local and global values [6, p. 11-12]. Educational systems in almost all regions of the world are subject to powerful diversification processes [7].

Now every year the knowledge is changed through the estimates by $15 \%$, if the counter of knowledge on the planet doubled every 30 years at the beginning of the century. The device "education for life" was changed by a new one as "lifelong learning". The new education paradigm requires the individualization and differentiation of education, the variability and alternativeness of educational systems and educational institutions, the flexibility and dynamism of educational and program documentation, its predictability and adaptability to the changing conditions of the socio-economic environment and the individual interests and abilities of students.

The reality of today can be considered concurrency at the domestic and interstate levels. The competitiveness of states in the global extra-education market [8] requires the demonstration of mechanisms to ensure its quality.

Increased interest and attention to the problems of quality assurance in the higher education system is typical not only for individual European countries, but also for the European Union as a whole. In many European countries, the concepts of the quality of the educational process have begun to attract attention from the beginning of the 80 s of the last century. In the United Kingdom in 1984, the view was expressed [9] that the main targets in the evaluation of the higher education system should be "quality" and "investment". In the same year, a National Quality Committee was organized in Greece. In the Netherlands, in 
1985, a government document was published under the title "Higher Education: Autonomy and Quality". In a number of other countries, discussions have begun on the need to introduce a quality system into the structure of higher education.

In 1991, the Commission of the European Community published a Memorandum on Higher Education [10], which expanded its role in preparing future European citizens, strengthening the idea of European citizenship, creating the European Union. Priorities for the development and transformation of higher education institutions in European countries were formulated, which were later consonant with the provisions of the Sorbonne and Bologna Declarations.

In 1995, the UN Commission on Education, Science and Culture (UNESCO), pursuant to the decisions of its General Conference, developed a Program document entitled "Reform and Development of Higher Education" [11], which summarized the global trends and challenges the development of higher education at the turn of the century.

The chronology of the reforms and transformations taking place in the field of education shows that quality assurance with regard to education is inherent in the academic environment. The assessment of the quality of education, which dates back to the $80 \mathrm{~s}$ of the last century, gradually acquired a public function. The governments of a number of European countries have abandoned centralized regulation of the higher education system and declared their readiness to provide more autonomy to universities, provided they guarantee the quality of education. Thus, the results of education are put forward in the center of activities for its reform. This in turn meant a change in emphasis: from the orientation of the educational process towards the teacher to the orientation towards the student.

The World Declaration on Higher Education for the 21st Century [12], adopted at the World Conference on Higher Education supported by UNESCO, reconfirmed the above as the following: "Quality in higher education is a multidimensional concept that should cover all its functions and activities: educational and academic programs; research and scholarships; staffing; students; building; material and technical base; equipment; work for the good of society and the academic environment."

Moreover, at the UNESCO World Conference on Higher Education [13] it was underlined that one of the main problems of higher education is to provide the quality of training of professionals.

On May 25, 1998, the ministers of higher education of France, Italy, Great Britain and Germany at the Sorbonne signed a tied declaration "On the Harmonization of the Architecture of the European Higher Education System" [14]. The first step to Bologna was the declaration.

V.I. Ivanova [15] notes that the Bologna process is not universally binding, has an open, democratic nature. Its main goal is to create by 2010 a single European educational space and increase the competitiveness of the European school in the world.

According to V.I. Baidenko [16], questions of the quality of education constitute the "core" of the majority of the Bologna reform packages. They are the kernel of the Bologna process. As it is considered for quality, the summarize is made in Trends III which is the basis of cooperated action on the "Bologna scene".

Finally, independent associations for quality assurance in higher education were created in European countries. These are civil society institutions that form the mechanisms of "feedback" of the interests of society, universities, students, employers and the state. They were called to conduct external examinations of the activities of the university in the form of assessment, accreditation and audit. Independent associations generate information for consumers. Their activity contributes to the screening of unscrupulous producers of educational services, helps to adapt the educational programs of universities to the needs and trends in labor markets. 
The joint documents of the ministers of education of European countries set a specific goal for the countries participating in the Bologna process - to develop existing quality assurance systems.

New institutional structures and mechanisms for their cooperation are designed to enhance the quality and development of European higher education institutions, in the Bologna participating countries they influence quality assurance systems and practices at the national and institutional levels, and in universities - quality assurance systems and procedures at all levels of high school.

The analysis of methods for ensuring and assessing the quality of higher education abroad demonstrates different approaches and traditions in different countries. However, one way or another, the different approaches and assessment systems focus on resources, processes and results. The differences relate to what more attention is paid to and to what extent. The society and the parties interested in high quality education in the conditions of intensifying competition in the educational services market need innovative mechanisms for its provision.

In world practice, there are the following quality assurance mechanisms: internal (using various methods of self-assessment, involving the young people in the quality estimation process, building a quality management system and quality branch) and external (delivering accreditation and certification processes, involving employers and guardians of students in quality essessment). Therefore, quality assurance of higher education refers to the processes of assessment, self-assessment and accreditation, as well as the creation of an internal university quality management system (QMS).

The Bologna process develops internal quality assurance practices. Trends III states that "... internal quality assurance mechanisms and evaluation are as common as external ones." The development of internal and external mechanisms to ensure the quality of education in different countries is expressed in different ways.

Different ways for estimating the quality of education are used depending on the national properties of the education system over the world, in general, agencies for estimating the quality of education apply a three-level process: internal estimation, external estimation and decision-making process based on external expert estimation. The basic traditional elements of the ways, which can be concluded as administrative and pedagogical, are approximately equal for all countries. These differences correspond mainly to the forms of estimation of individual success of students (internal way) and the methods of accreditation of universities or other procedures, allowing to prove the status nature of the university (external way). Particular emphasis is located on creating guarantees for an objective and independent quality estimation. This leads the transfer of authority to estimate the quality of higher education to private branches in which independent foreign experts should take part.

The separation of existing in the world estimation systems of higher education into two types has been shown by the analysis of world experience. The system of assessment of higher education in the countries where there are relevant state structures controlling the development of higher education is the first type, for instance, the ministries of education. The evaluation system is founded on the priority of state organizations in these cases.. Simultaneously, self-estimation is in the background, and the main efforts are created to deliver an effective external estimation by state bodies. The system of assessment of higher education, adopted in those countries where, in general, there are no government bodies for higher education (in the European sense) is the second type.. In this case, the process of selfestimation of higher educational institutions, aimed at internal analysis of university development (professional and public assessments), prevails. 


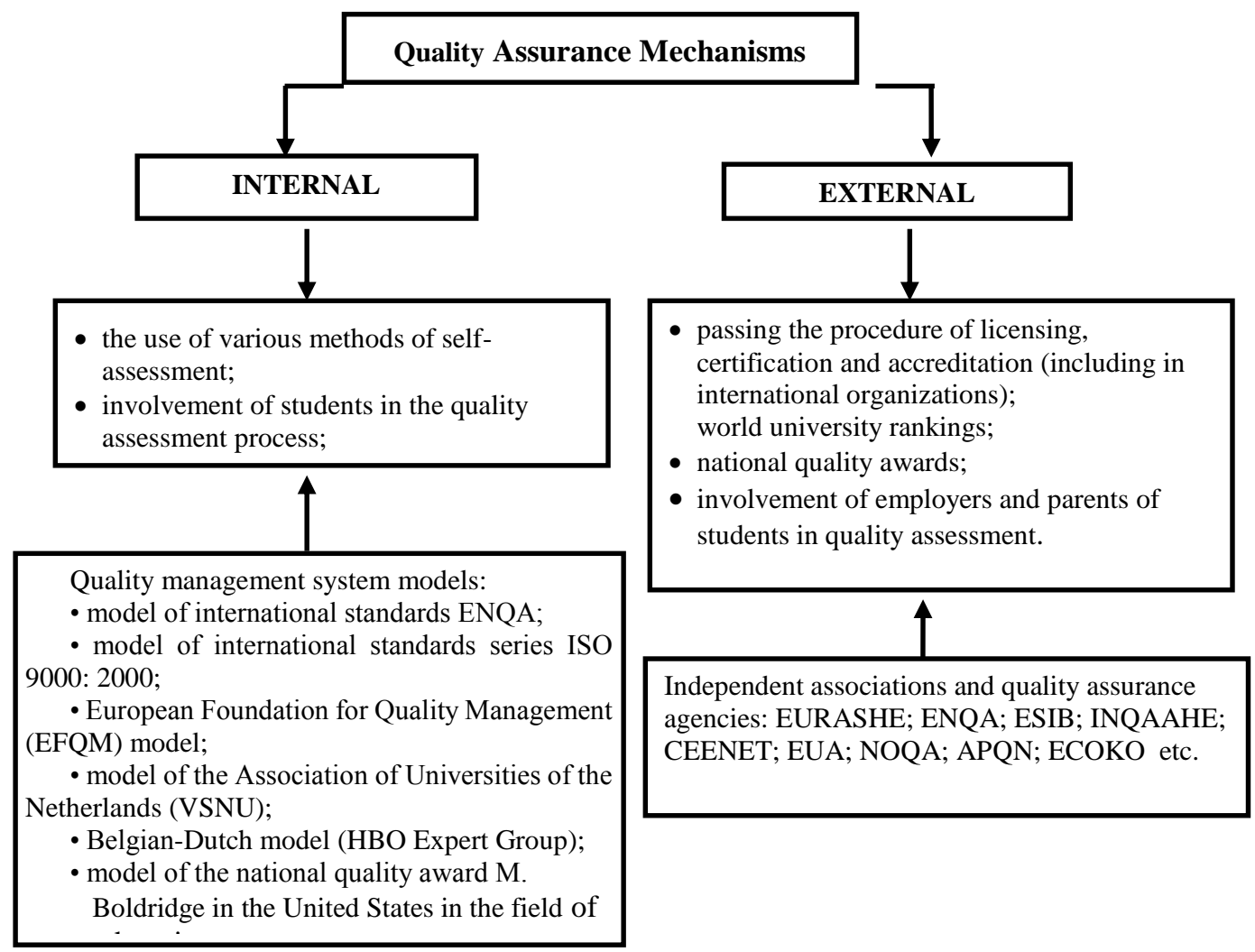

Figure 1 - Quality Assurance Mechanisms

Table 1

On the basis of a comparative analysis of landmark events (Table 1) on the quality of education in European countries, two periods were distinguished: 1 period - before the Bologna process; 2 period - after the Bologna process.

Three levels of quality assurance in higher education have been defined: 1) at the level of Europe $\rightarrow$ at the national level $\rightarrow$ at the level of a specific institution of higher education; 2) internal and external support ways.

\section{Conclusion}

The requirements of a market economy and modern improvement conditions in the country lead to reconsider the management of the educational process of Kazakhstan universities. A systematic analysis of literary sources shows that education management has not completely shifted to a qualitatively new style of work. The study allows us to conclude that the global integration processes and the international practice of forming a national system for ensuring the quality of higher education necessitate the creation of a quality assurance system in the university with appropriate mechanisms as an important tool to increase the competitiveness of the university and the quality of education in general. 


\section{References}

1 Message from the President to the people of Kazakhstan, Kazakhstanskaya Pravda (March 19th.2004)

2 N. A. Selezneva, Higher education today, 4 35-44 (2004)

3 State program for the development of education and science of the Republic of Kazakhstan for 2020 - 2025. Approved by the Decree of the Government of the Republic of Kazakhstan dated December 27, 2019 No. 988

4 Strategic Plan of the Ministry of Education and Science of the Republic of Kazakhstan for 2010-2014. Approved by the Government of the Republic of Kazakhstan on January, 29 (2010).

5 O. G. Golichenko, Higher education and science: integration or partnership // Economics and Mathematical Methods, 1 (121) (2005)

6 Higher education in Europe (2002) - V. XXVII. - №4. (http://www.aha.ru/ moscow64/educational_book).

7 Higher education in Europe (2002) - V. XXVII. - №1-2. (http://www.aha.ru/ moscow64/educational_book).

8 Higher education in Europe ( 2002) - V. XXVII. - №3. (http://www.aha.ru/ moscow64/educational_book).

9 E.V. Klycheva, O. P. Merkulova, Ensuring the quality of the educational process (faculty level): scientific method. Materials, (28) (Volgograd: Peremena, 2000)

10 Memorandum of Higher Education in the European Community // Commission of the European Communities. - Brussels, 1991.

11 Reform and development of higher education. Program document. - Paris: UNESCO, 1995; http://www.unesco.org/Education.

12 G. S. Minazheva, A. A. Nurmagambetov, Z. B. Salkynbaev, Strategy for the development of higher education in Europe: documents. - Almaty: Kazak University) 2004. $-148 \mathrm{p}$.

13 UNESCO World Conference on Higher Education. Higher education quality // Alma Mater. - 1999. - № 1. - pp. 30-37.

14 "Sorbonne Joint Declaration". Joint declaration on harmonization of the architecture of the European higher education system by the four Ministers charge for France, Germany, Italy and the United Kingdom. - Paris, 1998. May 25 http://www.bologna-berlin2003.de

15 Ivanova V.I. The Bologna Process and Russian Higher Education // Pedagogy, 2006. - №1. - pp. 97-106.

16 The Bologna Process: The Middle of the Way ed. dr ped Sciences, Professor V.I. Baydenko. - M : Research center problems quality prepared specialists. National accreditation center of the Ministry of Education and Science of the Republic of Kazakhstan, 2006. - 400 p. 